\title{
Knowledge and Practice of COVID-19 Infection Control Among Dental Students and Interns: A Cross-Sectional Survey
}

\author{
Azizah Bin Mubayrik (D) \\ Sara Al Dosary' \\ Wasayef Alwasil ${ }^{2}$ \\ Bushra AIShanqeeti ${ }^{2}$ \\ Maryam Alkathiri ${ }^{2}$ \\ Reem Alahmari (iD ${ }^{2}$ \\ Sarah Bin Sultan ${ }^{2}$ \\ 'Oral Medicine and Diagnostic Science \\ Department, King Saud University, \\ Riyadh, Saudi Arabia; ${ }^{2}$ Interns, College of \\ Dentistry, King Saud University, Riyadh, \\ Saudi Arabia
}

\begin{abstract}
Introduction: To assess the knowledge and practice of dental students and interns regarding coronavirus disease (COVID-19) based on academic level and university.

Materials and Methods: A cross-sectional survey was carried out among interns and dental students using self-administered, structured questionnaire regarding knowledge and clinical practice with respect to COVID-19 pandemic.

Results: A total of 126 completed questionnaires were received. A majority of the study participants (98.4\%) stated they were aware of the COVID-19 infection control policies. Most participants $(83.3 \%)$ had attended training or lectures about COVID-19. Most of them stated that the N59 mask is the best mask against the disease (81.7\%). Significant variations between academic years and genders were revealed regarding the clinical practice. Uncertainty existed regarding quarantining, preprocedural mouth wash, and handwashing versus desensitizing.

Conclusion: The level of knowledge of the participants was reasonable. Areas of deficiency in knowledge were observed among junior dental students. Further training in infection control measures and formulation of new guidelines are recommended to increase the knowledge and preparation of dental students regarding COVID-19 in dental settings, as well as reduce the transmission of infection.
\end{abstract}

Keywords: coronavirus disease, infection control, dental students, knowledge, disease transmission

\section{Introduction}

In December 2019, in Wuhan, China, numerous pneumonia cases caused by a new $\beta$-coronavirus were identified. ${ }^{1}$ This pneumonia has spread to many other countries to be a pandemic with most of the countries being affected. ${ }^{2,3}$ This condition, caused by the virus Severe Acute Respiratory Syndrome-Coronavirus-2 (SARSCoV-2), has been termed Coronavirus disease 2019 (COVID-19) and declared a pandemic by the World Health Organization (WHO) in March 2020 Contamination with SARS-CoV-2 is mainly airborne and through direct contact. $^{5,6}$ Droplets released after exhalation, coughing, or sneeze cause airborne contamination. ${ }^{5,6}$ At the same time, contact with contaminated surfaces and with the eyes, nose, or mouth causes direct contamination. ${ }^{7}$ Particles from droplets remain in suspension in for a length of time that depends on their size, settling velocity, relative humidity, and airflow in which droplets can spread up to $1 \mathrm{~m}$ if $>5 \mu \mathrm{m}$ in diameter and more than $1 \mathrm{~m}$ if the nuclei of the droplets have a diameter of
Correspondence: Azizah Bin Mubayrik Oral Medicine and Diagnostic Science Department, College of Dentistry, King Saud University, Riyadh, Saudi Arabia

Email aalmobeirik@ksu.edu.sa 
$<5 \mu \mathrm{m} .{ }^{8}$ In addition, it has been reported that even in the absence of clinical symptoms, the virus can still spread. ${ }^{9,10}$ Health care workers are considered the category of the highest diffusion of contagion. ${ }^{11}$ Dental practitioners in particular are at high risk of infection during their routine practice due to their exposure to saliva, blood, and droplet production. ${ }^{6,10,12,13}$ Therefore, during dental procedures, the transmission of SARS-CoV-2 can happen from infected individuals through the inhalation of their aerosols/droplets or directly through contact with oral fluids, mucous membranes, and contaminated instruments and surfaces. ${ }^{10,11,14}$ As such, studies have been performed to assess the level of awareness, perception, and attitude of dentists toward this pandemic and practice modifications along with other related factors that dentists should take into consideration. ${ }^{15-18}$ However, limitations and gaps were noticed in studies discussing those aspects among dental students in particular. The goal of the current study is to assess the knowledge and attitude toward COVID-19 of dental students and how well they are prepared for such a pandemic situation in their dental schools. This study aimed to assess the knowledge and clinical practice of dental students and interns during COVID-19 pandemics. Moreover, by the end of this study, gaps and deficiencies of knowledge and preparedness among dental students and interns will be identified, hence decreasing the risk of transmission of this and any future similar diseases.

\section{Materials and Methods}

A cross-sectional survey was carried out to assess the knowledge and practice of dental students and interns regarding COVID-19. A structured self-administered questionnaire was designed and constructed after reviewing the currently available literature. The questionnaire was divided into three parts. Part 1 contains questions about the demographic profile and characteristics of the study participants. Part 2 contains questions on the knowledge of some aspects of infection control policies. Part 3 was designed to investigate the clinical practice of the study participants. The questionnaire employed a fivepoint Likert scale, the points indicating measures ranging from strongly agree to strongly disagree. The questionnaires were anonymous and contained no private information about the participants. Participation in this study was completely voluntary. First, a pilot study was undertaken, and we questioned 25 individuals with different
Table I Sociodemographic and Characteristics of the Sample

\begin{tabular}{|l|l|l|}
\hline \multirow{2}{*}{ Variable } & \multicolumn{2}{c|}{ Gender } \\
\cline { 2 - 3 } Yearale & Male \\
\hline Ist year & $8(6.3)$ & $0(0)$ \\
\hline 2nd year & $14(11.1)$ & $4(3.2)$ \\
\hline 3rd & $10(7.9)$ & $6(4.8)$ \\
\hline 4th year & $14(11.1)$ & $3(2.4)$ \\
\hline 5th year & $53(42.1)$ & $8(6.3)$ \\
\hline Intern & $6(4.8)$ & $0(0)$ \\
\hline University & & $21(16.7)$ \\
\hline Governmental & $89(70.6)$ & $0(0)$ \\
\hline Private & $16(12.7)$ &
\end{tabular}

What PPE do you use while you are working at the clinic?

\begin{tabular}{|l|l|l|}
\hline All barriers & $43(34 . \mathrm{I})$ & $14(\mathrm{II} . \mathrm{I})$ \\
\hline $\begin{array}{l}\text { All barriers but no head } \\
\text { cap }\end{array}$ & $36(28.6)$ & $\mathrm{I}(0.8)$ \\
\hline Gloves, mask & $2(1.6)$ & $0(0)$ \\
\hline Not in the clinic yet & $23(18.3)$ & $6(4.8)$ \\
\hline
\end{tabular}

What PPE do you use while you are working at the laboratory?

\begin{tabular}{|l|l|l|}
\hline All barriers & $32(25.4)$ & $10(7.9)$ \\
\hline $\begin{array}{l}\text { All barriers but no head } \\
\text { cap }\end{array}$ & $54(42.9)$ & $8(6.3)$ \\
\hline Gloves, mask, gown & 10 & $2(1.6)$ \\
\hline Gloves, gown, shield & $2(1.6)$ & $0(0)$ \\
\hline Gloves, mask & $5(4)$ & $1(0.8)$ \\
\hline Mask & $2(1.6)$ & 0 \\
\hline Which type of masks do you use? & $54(42.9)$ & $7(5.6)$ \\
\hline Surgical mask & $28(22.2)$ & $10(7.9)$ \\
\hline N95 masks & 1 (0.8) & $0(0)$ \\
\hline Respirators & $22(17.5)$ & $4(3.2)$ \\
\hline Barrier masks & $102(8 I)$ & $21(16.7)$ \\
\hline Are you aware of COVID-19 infection control policies? & $0(0)$ \\
\hline Yes & $3(2.4)$ & \\
\hline No & & \\
\hline
\end{tabular}

(Continued) 
Table I (Continued).

\begin{tabular}{|l|l|l|}
\hline \multirow{2}{*}{ Variable } & \multicolumn{2}{|c|}{ Gender } \\
\cline { 2 - 3 } & Female & Male \\
\hline $\begin{array}{l}\text { Have you attended any training or lecture regarding COVID- } \\
\text { I9 and infection control? }\end{array}$ & $87(69)$ & $18(14.3)$ \\
\hline Yes & $18(14.3)$ & $3(2.4)$ \\
\hline No & & \\
\hline
\end{tabular}

academic levels to assess clarity and feasibility of the questionnaire. Results of the pilot study revealed that the questionnaire was easy to understand and took approximately between 5 and 10 minutes to complete. Therefore, no further adjustments were required. A questionnaire created using Google survey forms was distributed thereafter to a convenient sample group through social media outlets such as Twitter and the WhatsApp application.

\section{Statistical Analysis}

Data were collected and analyzed, after which they were summarized and presented in tables. All statistical analyses were performed using the Statistical Package for Social Sciences program (version 22). Descriptive statistics like frequency distributions were performed. $t$-tests and one-way analysis of variance (ANOVA) and posthoc analysis were used to measure the relationship between variables. P-values $\leq .05$ were considered statistically significant.

\section{Ethical Considerations}

The study proposal was approved by the College of Dentistry Research Center, King Saud University, Riyadh, Saudi (KSU-IRB 017E). All participants filled informed consent with a brief description about the study and the aim prior to participating.

\section{Results}

A total of 126 completed questionnaires were received. The sociodemographic data and sample characteristics are summarized in Table 1. A majority of the study participants (98.4\%) were aware of the COVID-19 infection control policies. Most of the participants (83.3\%) had attended training or at least a lecture on COVID-19. Multiple sources of information were used to obtain knowledge about the coronavirus (Figure 1). Only 9.5\% of the study participants would use all the required personal barriers (PPE) and 67.5\% would use multiple PPE, but not all PPE. Females were significantly more likely to comply with the use of PPE than males $(p=0.010)$. Figure 2 shows the knowledge of the study participants about different infection control aspects. The participants' responses regarding clinical practice are represented in Figure 3 and Table 2.

A $t$-test analysis of clinical practice versus gender and university and ANOVA are summarized in Tables 3 and 4. The ANOVA test showed significant variations between academic year groups. The Scheffe post-hoc test indicated a significant difference between the second-year group and other groups. They tended more to disagree with the fact that respiratory droplets, saliva, and other secretions and

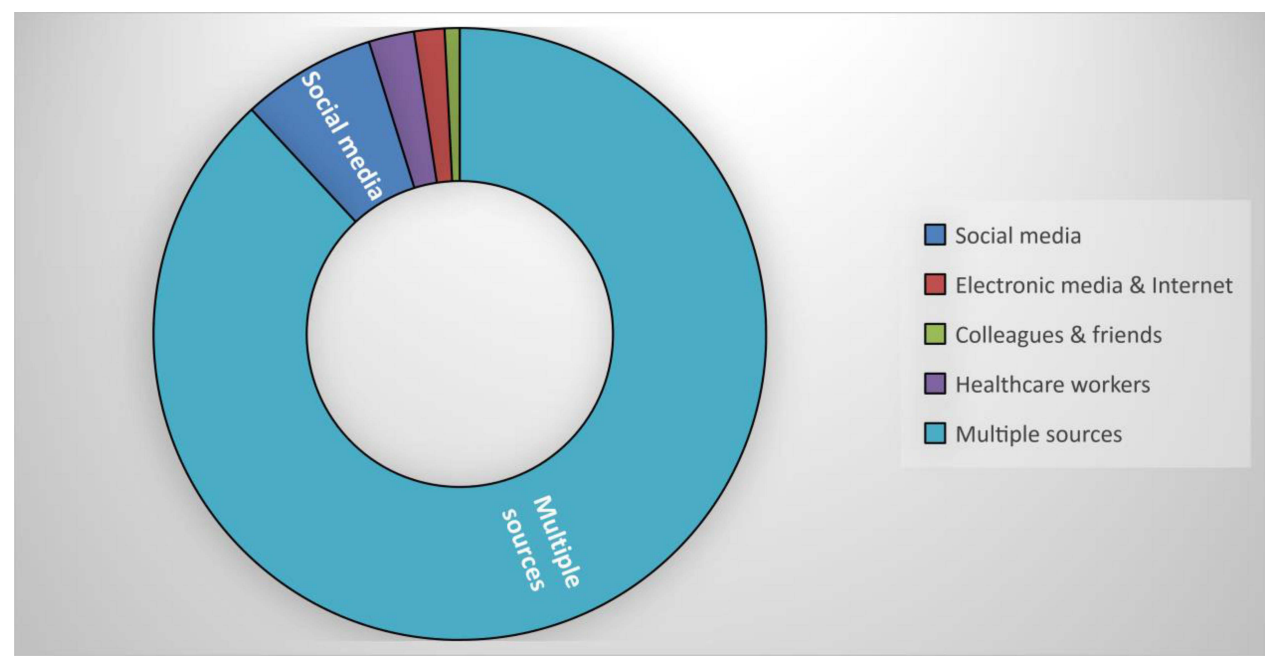

Figure I Sources of information regarding COVID-I9. 


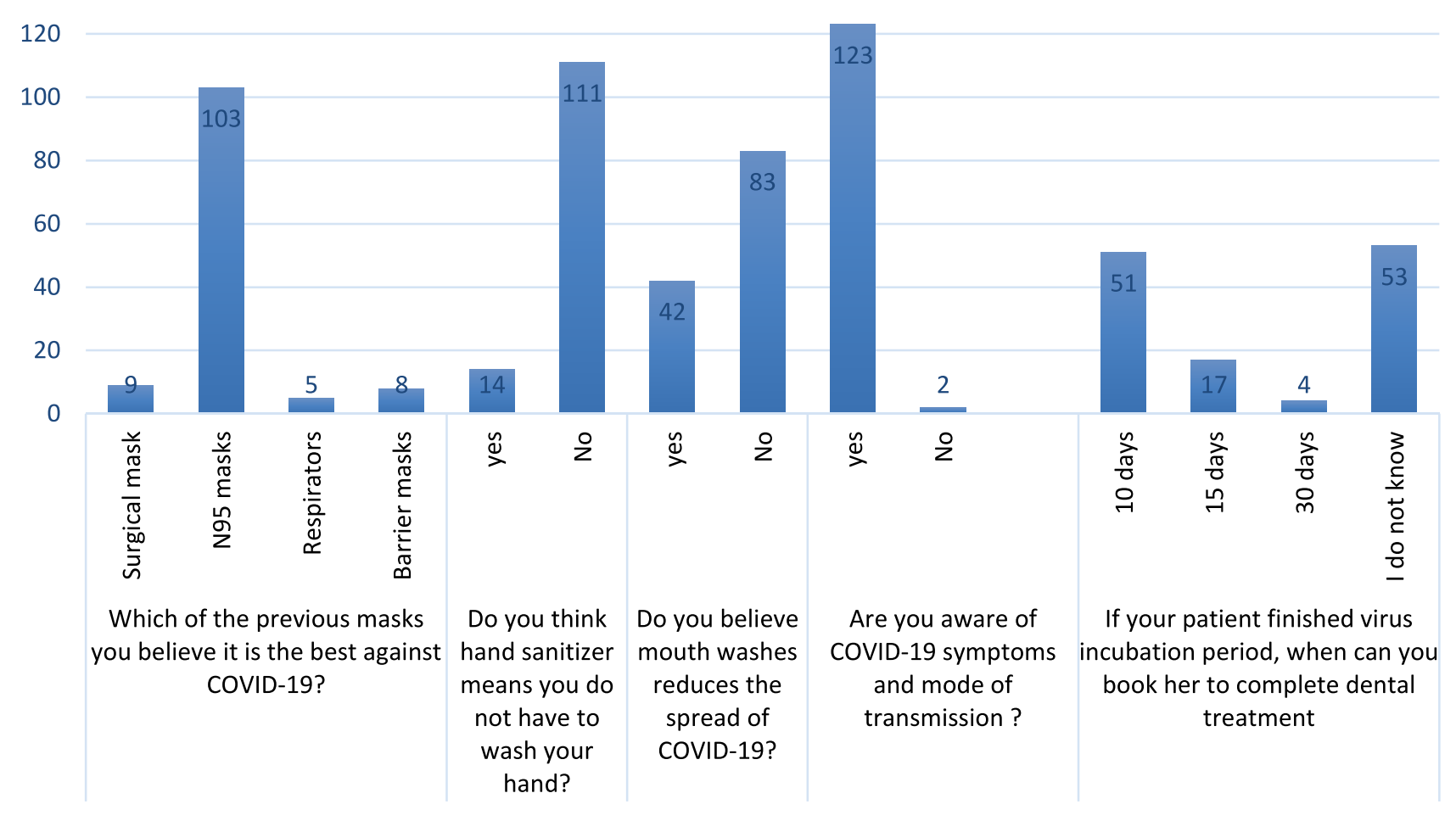

Figure 2 Knowledge among the study participants regarding different aspects of infection control.

contaminated surfaces were the main source of infection spread. The first and second years were more prone to disagree with the fact that respiratory droplets could transmit COVID-19 if within 1 meter of an infected person. They were also more likely to disagree that an initial screening should be done before appointment by telephone or with teledentistry. On the other hand, fifth-year students disagreed with the initial visit being face to face and not exceeding $15 \mathrm{~min}$. Third-year students were against the use of disposable diagnostic equipment, but tended to use rubber dams.

\section{Discussion}

This study aimed to assess the knowledge, attitude, and preparedness of the dental students and interns toward COVID-19; assessing the readiness aids in assessing the

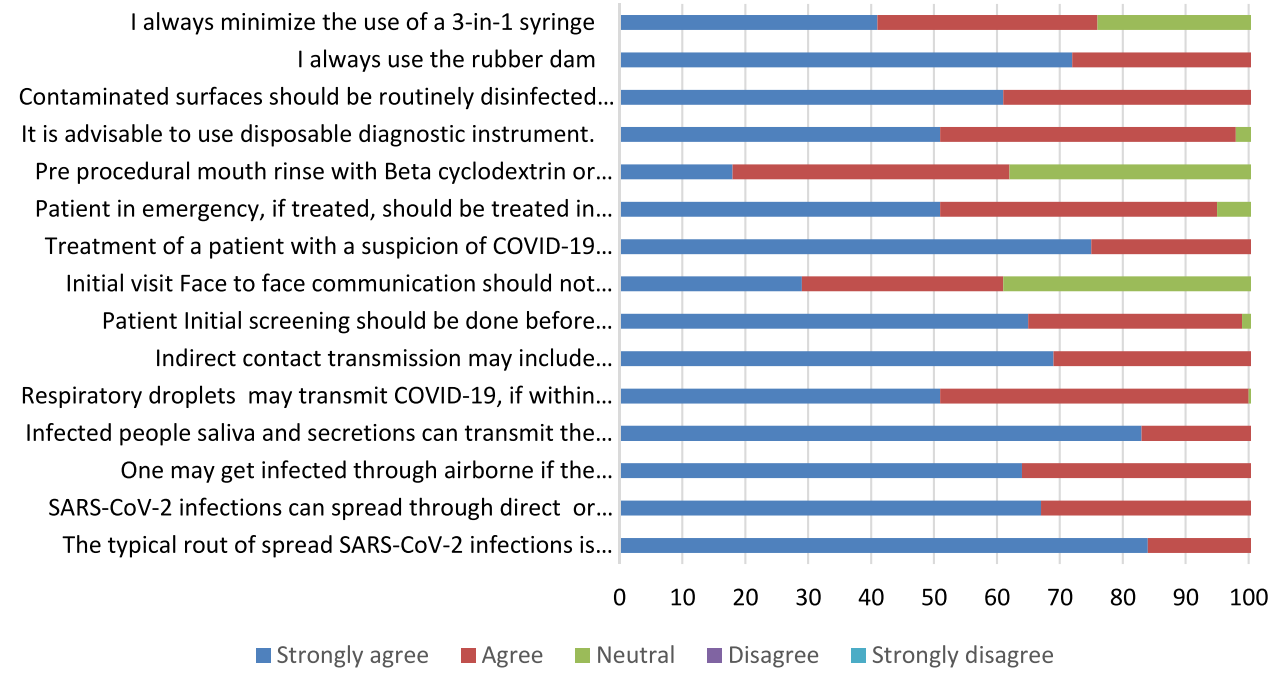

Figure 3 Participants' responses regarding clinical practice during COVID-19. 
Table 2 Participants' Responses Regarding Clinical Practice

\begin{tabular}{|c|c|c|c|c|c|}
\hline \multirow[t]{2}{*}{ Statement } & $\begin{array}{l}\text { Strongly } \\
\text { Agree }\end{array}$ & Agree & Neutral & Disagree & $\begin{array}{l}\text { Strongly } \\
\text { Disagree }\end{array}$ \\
\hline & n (\%) & n (\%) & n (\%) & n (\%) & n (\%) \\
\hline The typical rout of spread SARS-CoV-2 infection is respiratory droplets & $84(66.7)$ & $37(29.4)$ & $4(3.2)$ & $0(0)$ & I (0.8) \\
\hline SARS-CoV-2 infections can spread through direct or indirect contact & $67(53.2)$ & $37(29.4)$ & $15(11.9)$ & $7(5.6)$ & $0(0)$ \\
\hline $\begin{array}{l}\text { One may get infected through airborne if the potentially infecting individual is } \\
\text { within a distance of less than } 2 \mathrm{~m}\end{array}$ & $64(50.8)$ & $44(34.9)$ & $13(10.3)$ & $4(3.2)$ & I (0.8) \\
\hline Infected people's saliva and secretions can transmit the infection & $83(65.9)$ & $34(27)$ & $6(4.8)$ & $\mathrm{I}(0.8)$ & $2(1.6)$ \\
\hline $\begin{array}{l}\text { Respiratory droplets may transmit COVID-19 if within I meter of an infected } \\
\text { person }\end{array}$ & $51(40.5)$ & 49 (38.9) & $24(19)$ & $\mathrm{I}(0.8)$ & I (0.8) \\
\hline $\begin{array}{l}\text { Indirect contact transmission may include contaminated objects or clinic } \\
\text { surfaces }\end{array}$ & $69(54.8)$ & $45(35.7)$ & $9(7.1)$ & $2(1.6)$ & I (0.8) \\
\hline $\begin{array}{l}\text { Patient initial screening should be done before appointment by telephone or } \\
\text { teledentistry }\end{array}$ & $65(51.6)$ & $34(27)$ & $23(18.3)$ & $\mathrm{I}(0.8)$ & $3(2.4)$ \\
\hline Initial face-to-face visit should not exceed $15 \mathrm{~min}$ & $29(23)$ & $32(25.4)$ & $48(38.1)$ & $13(10.3)$ & $4(3.2)$ \\
\hline $\begin{array}{l}\text { Treatment of a patient suspected of having COVID-19 should be postponed for } \\
\text { a period of } 14 \text { to } 20 \text { days }\end{array}$ & $75(59.5)$ & $41(32.5)$ & $7(5.6)$ & $3(2.4)$ & $0(0)$ \\
\hline $\begin{array}{l}\text { A patient in emergency, if treated, should be so in negative pressure/airborne } \\
\text { infection isolation rooms }\end{array}$ & $51(40.5)$ & 44 (34.9) & $25(19.8)$ & $4(3.2)$ & $2(1.6)$ \\
\hline $\begin{array}{l}\text { Preprocedural mouth rinse with } \beta \text {-cyclodextrin or } 0.02 \% \text { povidone iodine } \\
\text { oxidative agents ( } 1 \% \text { hydrogen peroxide) may reduce the viral load }\end{array}$ & $18(14.3)$ & $44(34.9)$ & $59(46.8)$ & $3(2.4)$ & $2(1.6)$ \\
\hline It is advisable to use disposable diagnostic instruments & $51(40.5)$ & $47(37.3)$ & $25(19.8)$ & $3(2.4)$ & $0(0)$ \\
\hline $\begin{array}{l}\text { Contaminated surfaces should be routinely disinfected with } 62-71 \% \text { ethanol, } \\
0.5 \% \text { hydrogen peroxide, or } 0.1 \% \text { sodium hypochlorite }\end{array}$ & $61(48.4)$ & $54(42.9)$ & $10(7.9)$ & $\mathrm{I}(0.8)$ & $0(0)$ \\
\hline I always use the rubber dam & $72(57.1)$ & $34(27)$ & $14(1 \mathrm{I} .1)$ & $4(3.2)$ & $2(1.6)$ \\
\hline I always minimize the use of a 3 -in- I syringe & $41(32.5)$ & $35(27.8)$ & $4 \mathrm{I}(32.5)$ & $4(3.2)$ & $5(4)$ \\
\hline
\end{tabular}

level of knowledge and identifying the gaps, thus, decreasing the risk and prepare them for any similar future epidemics.

Similar to other studies, ${ }^{19-21}$ ours revealed that the majority of the participants were aware of the COVID-19 infection control policies. This is in contrast to Kashif et al, who reported insufficient awareness. ${ }^{22}$ In his study, most of the knowledge gap was associated with donning and doffing PPE procedures. The results of the study by Al-Khalifa et al demonstrated variability of awareness based on rank and experience. ${ }^{20}$ The authors' findings indicated that consultants, specialists, and dentists with more than ten years' worth of experience have better awareness. ${ }^{20}$ Our study demonstrated good compliance with PPE use. The lack of head cap wear is possibly due to the use of the veil to cover the hair among females. The importance of PPE cannot be overlooked. This involves the use of all barriers such as facemasks, eye protection with lateral shields, protective clothing along with adequate disinfection of clinical premises, proper sterilization of the dental equipment and instruments, and regular vaccination of dental healthcare workers. ${ }^{23-25}$

Our investigation showed that females were more likely to comply with infection control policies than males. Men were reported to use PPE less frequently than females and suffer more injuries due to sharp objects. $^{26-28}$ Compliance with infection control policies has been reported to be affected by several factors such 
Table 3 t-test for Clinical Practice versus Gender and University

\begin{tabular}{|c|c|c|c|c|c|c|}
\hline Statement & Gender & $\mathbf{N}$ & Mean & $\begin{array}{l}\text { Std. } \\
\text { Deviation }\end{array}$ & $\mathbf{T}$ & $\begin{array}{l}\text { Sig. } \\
\text { (Two- } \\
\text { Tailed) }\end{array}$ \\
\hline \multirow[t]{2}{*}{ SARS-CoV-2 infections can spread through direct or indirect contact } & Female & 105 & 4.41 & 0.817 & \multirow[t]{2}{*}{3.159} & \multirow[t]{2}{*}{0.002} \\
\hline & Male & 21 & 3.76 & 1.044 & & \\
\hline \multirow{2}{*}{$\begin{array}{l}\text { Respiratory droplets may transmit COVID-19 if within I meter of an } \\
\text { infected person }\end{array}$} & Female & 105 & 4.10 & 0.820 & \multirow[t]{2}{*}{-2.301} & \multirow[t]{2}{*}{0.028} \\
\hline & Male & 21 & 4.52 & 0.750 & & \\
\hline \multirow{2}{*}{$\begin{array}{l}\text { Treatment of a patient suspected of having COVID-19 should be postponed } \\
\text { for a period of } 14 \text { to } 20 \text { days }\end{array}$} & Female & 105 & 4.45 & 0.747 & \multirow[t]{2}{*}{-2.141} & \multirow[t]{2}{*}{0.038} \\
\hline & Male & 21 & 4.71 & 0.463 & & \\
\hline \multirow{2}{*}{$\begin{array}{l}\text { Preprocedural mouth rinse with } \beta \text {-cyclodextrin or } 0.02 \% \text { povidone iodine } \\
\text { oxidative agents ( } 1 \% \text { hydrogen peroxide) may reduce the viral load }\end{array}$} & Female & 105 & 3.69 & 0.812 & \multirow[t]{2}{*}{3.841} & \multirow[t]{2}{*}{0.001} \\
\hline & Male & 21 & 3.05 & 0.669 & & \\
\hline \multirow[t]{2}{*}{ The typical rout of spread SARS-CoV-2 infection is respiratory droplets } & Governmental & 110 & 1.33 & 0.607 & \multirow[t]{2}{*}{-2.956} & \multirow[t]{2}{*}{0.004} \\
\hline & Private & 16 & 1.81 & 0.655 & & \\
\hline \multirow{2}{*}{$\begin{array}{l}\text { A patient in emergency, if treated, should be so in negative pressure/ } \\
\text { airborne infection isolation rooms }\end{array}$} & Governmental & 110 & 4.03 & 0.962 & \multirow[t]{2}{*}{-3.397} & \multirow[t]{2}{*}{0.002} \\
\hline & Private & 16 & 4.56 & 0.512 & & \\
\hline \multirow[t]{2}{*}{ It is advisable to use disposable diagnostic instruments } & Governmental & 110 & 4.21 & 0.847 & \multirow[t]{2}{*}{2.508} & \multirow[t]{2}{*}{0.018} \\
\hline & Private & 16 & 3.81 & 0.544 & & \\
\hline \multirow{2}{*}{$\begin{array}{l}\text { Contaminated surfaces should be routinely disinfected with } 62-71 \% \text { ethanol, } \\
0.5 \% \text { hydrogen peroxide, or } 0.1 \% \text { sodium hypochlorite }\end{array}$} & Governmental & 110 & 4.45 & 0.644 & \multirow[t]{2}{*}{2.978} & \multirow[t]{2}{*}{0.003} \\
\hline & Private & 16 & 3.94 & 0.680 & & \\
\hline \multirow[t]{2}{*}{ I always use the rubber dam } & Governmental & 110 & 4.42 & 0.882 & \multirow[t]{2}{*}{2.255} & \multirow[t]{2}{*}{0.026} \\
\hline & Private & 16 & 3.88 & 1.025 & & \\
\hline
\end{tabular}

as experience, a positive attitude, and continuous education. Compliance was also reported to be higher during the COVID-19 pandemic. $^{28-30}$ Our study revealed that females use all barriers except the head cap.

There was some confusion concerning hand sanitizer, mouth wash before dental treatment, and when to treat after the incubation period. The respondents were unable to decide hand disinfection material to be used. Both liquid soap and hand sanitizer have been shown to be effective methods of decontamination. ${ }^{31}$

Our results showed that most of the respondents used multiple sources of information about COVID-19 followed by social media and healthcare workers. Kashif et $\mathrm{al}^{22}$ reported most of the participants got information about COVID-19 infection and guidelines through attending CME lectures or training. This is in contrast to the results of the study by Alanazi et al, ${ }^{32}$ who reported that students had limited knowledge about certain aspects of cross infection, and it is recommended to provide them with training about infection control as per international guidelines. In contrast, Kamate et $\mathrm{al}^{33}$ reported that the internet was the main resource for obtaining information about COVID-19 followed by social media among dentists. The development and spread of a new infectious agent stresses the importance and value of having access to trusted sources of information such as the Center of Disease Control and Prevention, the WHO, or the websites of health ministries of each country. ${ }^{33}$

Our investigation revealed a satisfactory level of PPE use. Alanazi et al emphasized the importance of PPE use in preventing cross infection that results from inhalation of droplets of oral and respiratory fluids; PPE such as face masks and protective eye wear must be used throughout the appointment and changed and disinfected immediately after use. $^{32}$ The use of PPE in the dental setting has been reported to protect dentists and reduce the risk of 
Table 4 ANOVA Analysis of Clinical Practice versus Academic Year

\begin{tabular}{|c|c|c|c|c|c|c|}
\hline \multicolumn{2}{|l|}{ Statement } & \multirow{2}{*}{$\begin{array}{l}\begin{array}{l}\text { Sum of } \\
\text { Squares }\end{array} \\
4.920\end{array}$} & \multirow{2}{*}{$\begin{array}{l}\text { df } \\
5\end{array}$} & \multirow{2}{*}{$\begin{array}{l}\begin{array}{l}\text { Mean } \\
\text { Square }\end{array} \\
0.984\end{array}$} & \multirow{2}{*}{$\begin{array}{l}\mathbf{F} \\
2.622\end{array}$} & \multirow{2}{*}{$\begin{array}{l}\text { Sig. } \\
0.027\end{array}$} \\
\hline The typical rout of spread SARS-CoV-2 infection is respiratory & Between Groups & & & & & \\
\hline droplets & Within Groups & 45.025 & 120 & 0.375 & & \\
\hline & Total & 49.944 & 125 & & & \\
\hline \multirow[t]{3}{*}{ Infected people's saliva and secretions can transmit the infection } & Between Groups & 8.597 & 5 & 1.719 & \multirow[t]{3}{*}{3.193} & \multirow[t]{3}{*}{0.010} \\
\hline & Within Groups & 64.617 & 120 & 0.538 & & \\
\hline & Total & 73.214 & 125 & & & \\
\hline \multirow{3}{*}{$\begin{array}{l}\text { Respiratory droplets may transmit COVID-19 if within I meter } \\
\text { of an infected person }\end{array}$} & Between Groups & 9.091 & 5 & 1.818 & \multirow[t]{3}{*}{2.907} & \multirow[t]{3}{*}{0.016} \\
\hline & Within Groups & 75.068 & 120 & 0.626 & & \\
\hline & Total & 84.159 & 125 & & & \\
\hline \multirow{3}{*}{$\begin{array}{l}\text { Indirect contact transmission may include contaminated objects } \\
\text { or clinic surfaces }\end{array}$} & Between Groups & 9.927 & 5 & 1.985 & \multirow[t]{3}{*}{3.795} & \multirow[t]{3}{*}{0.003} \\
\hline & Within Groups & 62.779 & 120 & 0.523 & & \\
\hline & Total & 72.706 & 125 & & & \\
\hline \multirow{3}{*}{$\begin{array}{l}\text { Patient initial screening should be done before appointment by } \\
\text { telephone or teledentistry }\end{array}$} & Between Groups & 16.816 & 5 & 3.363 & \multirow[t]{3}{*}{4.268} & \multirow[t]{3}{*}{0.001} \\
\hline & Within Groups & 94.557 & 120 & 0.788 & & \\
\hline & Total & 111.373 & 125 & & & \\
\hline \multirow[t]{3}{*}{ Initial face-to-face visit should not exceed $15 \mathrm{~min}$} & Between Groups & 28.540 & 5 & 5.708 & \multirow[t]{3}{*}{6.189} & \multirow[t]{3}{*}{0.000} \\
\hline & Within Groups & 110.674 & 120 & 0.922 & & \\
\hline & Total & 139.214 & 125 & & & \\
\hline \multirow[t]{3}{*}{ It is advisable to use disposable diagnostic instruments } & Between Groups & 10.952 & 5 & 2.190 & \multirow[t]{3}{*}{3.558} & \multirow[t]{3}{*}{0.005} \\
\hline & Within Groups & 73.874 & 120 & 0.616 & & \\
\hline & Total & 84.825 & 125 & & & \\
\hline \multirow[t]{3}{*}{ I always use the rubber dam } & Between Groups & 17.393 & 5 & 3.479 & \multirow[t]{3}{*}{4.785} & \multirow[t]{3}{*}{0.001} \\
\hline & Within Groups & 87.242 & 120 & 0.727 & & \\
\hline & Total & 104.635 & 125 & & & \\
\hline
\end{tabular}

nosocomial infections and cross transmission. ${ }^{34,35}$ Moreover, the majority of the participants were aware of most aspects of infection control, particularly when associated with mask use, symptoms, and mode of transmission of COVID-19. Likewise, dentists were reported to have a reasonable level of knowledge and awareness regarding PPE use, hand hygiene, and infection control guidelines for preventing COVID-19. ${ }^{33,36,37}$ However, a considerable number of study participants were confused between hand sanitizing and handwashing. Also, a high percentage of the participants were not sure when to book the patient after the incubation period to complete the dental treatment. In contrast, Aboalela et al in 2020, reported that all participants agreed that all elective dental treatments must be delayed, and only emergency treatments should be performed. ${ }^{38}$

The results of this study revealed inadequate knowledge about the possible role of preprocedural mouth rinsing in reducing the spread of COVID-19. In contrast, Aboalela et al found that the use of chlorhexidine mouth 
wash in the dental setting was more than that of hydrogen peroxide among undergraduates, though the latter is more effective in reducing the viral load. ${ }^{38}$

In this study, significant variations among senior and junior academic year groups were noted. The findings of our study indicated significant differences between the second-year group and other groups. They tended to disagree more with the fact that respiratory droplets, saliva, and other secretions as well as contaminated surfaces were the mode of infection spread. First- and second-year students were more likely to disagree with the fact that respiratory droplets might transmit COVID-19 if within 1 meter of an infected person. They were also more likely to disagree that an initial screening should be performed before booking an appointment by telephone or teledentistry. This might be due to the higher level of knowledge about clinical practice and applied infection control procedures among senior dental students as compared to juniors. The importance of telemedicine was emphasized in patients' follow-ups and triage. ${ }^{37}$

It is worth noting that other groups have compared to first- and second-year dental students, corresponding to the level of education that they obtained in dental school. Similarly, it was reported that qualifications and years of experience are associated with knowledge. ${ }^{33,38}$ Among senior students, fifth-year students disagreed more with the initial visit being face to face and not exceeding 15 min than fourth-year students. This might be due to their anticipation of a longer required time for the initial visit to gather all the required information for comprehensive dental treatment planning. Third-year students were against the use of disposable diagnostic equipment, but they were more likely to use the rubber dam. This could be explained by the fact that their training did not involve disposable equipment but included the mandatory use of the rubber dam in all clinical sessions. Thus, clinical training and instruction should address all possible clinical situations and alternatives that might be faced during future practice.

\section{Conclusion}

This study aimed to assess the knowledge and practice of the dental students and interns regarding COVID-19. In general, most participants were aware of the infection control policies and COVID-19 signs and symptoms. A deficiency in knowledge was observed mostly among junior dental students. Posting knowledge is one of the essential steps when dealing with such situations. We recommend more training for dental healthcare providers through lectures and hands-on student training on the infection control measures as well as clear guidelines to be followed during such a pandemic situation. This might increase their knowledge and, therefore, decrease the risk of transmission of the infection in the dental office.

\section{Data Sharing Statement}

Data are available upon request.

\section{Acknowledgments}

The author would like to express deepest thanks to the Researchers Support and Services Unit at King Saud University for their editorial assistance.

\section{Disclosure}

The authors report no conflicts of interest in this work.

\section{References}

1. Zhu N, Zhang D, Wang W, et al. A novel coronavirus from patients with pneumonia in China, 2019. N Engl J Med. 2020;382:727-733. doi:10.1056/NEJMoa2001017

2. Wang C, Horby PW, Hayden FG, Gao GF. A novel coronavirus outbreak of global health concern. Lancet. 2020;395:470-473. doi:10.1016/S0140-6736(20)30185-9

3. Liu T, Hu J, Kang M, et al. Transmission dynamics of 2019 novel coronavirus (2019-nCoV). 2020.

4. Ghebreyesus TA. WHO Director-General's Opening Remarks at the Media Briefing on COVID-19-11 March 2020. World Health Organization; 2020:11.

5. Chen N, Zhou M, Dong X, et al. Epidemiological and clinical characteristics of 99 cases of 2019 novel coronavirus pneumonia in Wuhan, China: a descriptive study. Lancet. 2020;395:507-513. doi:10.1016/S0140-6736(20)30211-7

6. Peng X, Xu X, Li Y, Cheng L, Zhou X, Ren B. Transmission routes of $2019-\mathrm{nCoV}$ and controls in dental practice. Int J Oral Sci. 2020;12:1-6. doi:10.1038/s41368-020-0075-9

7. Alhazzani W, Møller MH, Arabi YM, et al. Surviving sepsis campaign: guidelines on the management of critically ill adults with Coronavirus Disease 2019 (COVID-19). Intensive Care Med. 2020;46:854-887. doi:10.1007/s00134-020-06022-5

8. Lo Giudice R. The severe acute respiratory syndrome coronavirus-2 (SARS CoV-2) in dentistry. Management of biological risk in dental practice. Int $J$ Environ Res Public Health. 2020;17:3067. doi:10.3390/ijerph17093067

9. Huang C, Wang Y, Li X, et al. Clinical features of patients infected with 2019 novel coronavirus in Wuhan, China. Lancet. 2020;395:497-506. doi:10.1016/S0140-6736(20)30183-5

10. Fallahi HR, Keyhan SO, Zandian D, Kim SG, Cheshmi B. Being a front-line dentist during the Covid-19 pandemic: a literature review. Maxillofac Plast Reconstr Surg. 2020;42:1-9. doi:10.1186/s40902020-00256-5

11. Izzetti R, Nisi M, Gabriele M, Graziani F. COVID-19 transmission in dental practice: brief review of preventive measures in Italy. $J$ Dent Res. 2020;99:1030-1038. doi:10.1177/0022034520920580

12. Meng L, Hua F, Bian Z. Coronavirus disease 2019 (COVID-19): emerging and future challenges for dental and oral medicine. J Dent Res. 2020;99:481-487. doi:10.1177/0022034520914246 
13. $\mathrm{Xu} \mathrm{H}$, Zhong L, Deng J, et al. High expression of ACE2 receptor of 2019-nCoV on the epithelial cells of oral mucosa. Int J Oral Sci. 2020;12:1-5. doi:10.1038/s41368-020-0074-X

14. Kampf G, Todt D, Pfaender S, Steinmann E. Persistence of coronaviruses on inanimate surfaces and their inactivation with biocidal agents. $J$ Hos Infect. 2020;104:246-251. doi:10.1016/j. jhin.2020.01.022

15. Consolo U, Bellini P, Bencivenni D, Iani C, Checchi V. Epidemiological aspects and psychological reactions to COVID-19 of dental practitioners in the northern Italy Districts of Modena and Reggio Emilia. Int J Environ Res Public Health. 2020;17:3459. doi:10.3390/ijerph17103459

16. Khader Y, Al Nsour M, Al-Batayneh OB, et al. Dentists' awareness, perception, and attitude regarding COVID-19 and infection control: cross-sectional study among Jordanian dentists. JMIR Public Health Surveill. 2020;6:e18798. doi:10.2196/18798

17. Ahmed MA, Jouhar R, Ahmed N, et al. Fear and practice modifications among dentists to combat novel coronavirus disease (COVID-19) outbreak. Int $J$ Environ Res Public Health 2020;17:2821. doi:10.3390/ijerph17082821

18. Fini MB. What dentists need to know about COVID-19. Oral Oncol. 2020;105:104741. doi:10.1016/j.oraloncology.2020.104741

19. Kanaparthi A, Dukkireddy D, Gopalaiah H, Kesary SPR, Katne T, Gantala R. Awareness of COVID 19 pandemic among dental practioners of Telangana state, India: a cross sectional survey. J Oral Biol Craniofac Res. 2020;10:484-489. doi:10.1016/j.jobcr.2020.08.001

20. Al-Khalifa KS, AlSheikh R, Al-Swuailem AS, et al. Pandemic preparedness of dentists against coronavirus disease: a Saudi Arabian experience. PLoS One. 2020;15:e0237630. doi:10.1371/journal. pone. 0237630

21. Zaheer R, Tanveer A, Khan M, Jan A, Awan SZ. Awareness of precautionary measures against Covid-19 in healthcare workers. Pak Armed Forces Med J. 2020;70:S261-S268.

22. Kashif S, Pervaiz E, Azam F, Waqar T, Babar A, Gul A. Awareness regarding personal protective equipment use among health care providers in various tertiary hospitals across Pakistan during Covid-19 pandemic. Pak Armed Forces Med. 2020;70:S518-S522.

23. Brodhead F. The importance of PPE and regular testing in health care facilities. Am J Nurs. 2020;120:17. doi:10.1097/01. NAJ.0000724192.19536.92

24. Tian Z, Stedman M, Whyte M, Anderson SG, Thomson G, Heald A. Personal protective equipment (PPE) and infection among healthcare workers - what is the evidence? Int J Clin Pract. 2020;74:e13617. doi:10.1111/ijcp. 13617

25. Abreu MH, Lopes-Terra MC, Braz LF, Rímulo AL, Paiva SM, Pordeus IA. Attitudes and behavior of dental students concerning infection control rules: a study with a 10-year interval. Braz Dent J. 2009;20:221-225. doi:10.1590/S0103-64402009000300009

26. Ward D. Gender differences in compliance with infection control precautions. Br J Infect Control. 2004;5:17-19. doi:10.1177/ 14690446040050010401
27. Sharir R, Teitler N, Lavi I, Raz R. High-level handwashing compliance in a community teaching hospital: a challenge that can be met! $J$ Hosp Infect. 2001;49:55-58. doi:10.1053/jhin.2001.1049

28. Jemal K, Gashaw K, Kinati T, Bedada W, Getahun B. Clean and safe healthcare environment: knowledge, attitude, and practice of infection prevention and control among health workforce at north showa zone Oromiya region. J Environ Pub Health. 2020;2020:1-10. doi:10.1155/2020/6021870

29. Alqahtani SS. Compliance with infection control practices among healthcare practitioners in Saudi Arabia during coronavirus pandemic: cross-sectional study. Middle East $J$ Intern Med. 2020;13:46-54.

30. Zakout YM, Khatoon F, Bealy MA, Khalil NA, Alhazimi AM. Role of the coronavirus disease 2019 (COVID-19) pandemic in the upgrading of personal hygiene. A cross-sectional study in Saudi Arabia. Saudi Med J. 2020;41:1263-1269. doi:10.15537/ smj.2020.11.25402

31. Khairnar MR, Anitha G, Dalvi TM, et al. Comparative efficacy of hand disinfection potential of hand sanitizer and liquid soap among dental students: a randomized controlled trial. Indian J Critl Care Med. 2020;24:336. doi:10.5005/jp-journals-10071-23420

32. Alanazi AO, Alrawili YK, Alanazi YM, Shah FA. Knowledge and attitudes towards infection control protocols among the students of Al-Jouf University in Saudi Arabia. Egypt $J$ Hosp Med. 2018;71:3328-3331.

33. Kamate SK, Sharma S, Thakar S, et al. Assessing knowledge, attitudes and practices of dental practitioners regarding the COVID-19 pandemic: a multinational study. Dent Med Probl. 2020;57:11-17. doi: $10.17219 / \mathrm{dmp} / 119743$

34. Fotedar S, Fotedar V, Sharma K, Bhardwaj V. Precautions in dentistry against swine flu. SRM J Res Dent Sci. 2013;4:161. doi:10.4103/ 0976-433X.125593

35. Leder K, Torresi J, Libman MD, et al. GeoSentinel surveillance of illness in returned travelers, 2007-2011. Ann Intern Med. 2013;158:456-468. doi:10.7326/0003-4819-158-6-201303190-00005

36. Ajondi R, Alghamdi SS, Abdelaziz I, et al. Knowledge of COVID-19 infection control among healthcare workers in radiology departments in Saudi Arabia. J Radiat Res Appl Sci. 2020. doi:10.1080/ 16878507.2020 .1856587

37. Sinjari B, Rexhepi I, Santilli M, et al. The impact of COVID-19 related lockdown on dental practice in Central Italy-outcomes of a survey. Int $J$ Environ Res Public Health. 2020;17(16):5780. doi:10.3390/ijerph17165780

38. Aboalela A, Shafei AA, Shraim NM, Almousa MA, Alharbi GK, Alqahtani AS. Knowledge and awareness of COVID-19 among dental students, interns, clinicians and academics. Int $J$ Med Res Health Sci. 2020;9:25-31.
Advances in Medical Education and Practice

\section{Publish your work in this journal}

Advances in Medical Education and Practice is an international, peerreviewed, open access journal that aims to present and publish research on Medical Education covering medical, dental, nursing and allied health care professional education. The journal covers undergraduate education, postgraduate training and continuing medical education
Dovepress

including emerging trends and innovative models linking education, research, and health care services. The manuscript management system is completely online and includes a very quick and fair peer-review system. Visit http://www.dovepress.com/testimonials.php to read real quotes from published authors. 